\title{
Actions in Slow Motion: Theoretical and Methodological Reflections on Temporality in Actions and Intersubjective Understanding
}

\author{
Alexander Schmidl ${ }^{1}$
}

Accepted: 29 May 2021 / Published online: 23 June 2021

(c) The Author(s) 2021

\begin{abstract}
This article examines the connection between actions, temporality, and media-based observation. Slow motion technology is currently being used especially in sports to examine and evaluate athletes' actions more precisely in order to identify potential infringements of rules. Starting with a phenomenological perspective, this article engages in a critical assessment of the degree to which the intentions underlying athletes' actions become clearer if their actions are slowed down using slow motion. It transpires that a more in-depth understanding is not possible because the process of time-stretching using media technology tends to obscure intersubjective understanding. Nevertheless, the use of different playback speeds does increase observers' sensitivity to the temporality of action and observation. This is particularly the case when greater emphasis is placed on the body and its role in the formation and carrying out of intentions. With the phenomenological view and in special consideration of the body and the subjective intentionality, the paper contributes to a discussion about the connection of time and (inter-)action already led in ethnomethodology and conversation analysis. These findings mark a contribution to empirical social research as well, which is increasingly using video material in action analysis and should take slow motion as a possible augmented but also manipulated access to actions into account adequately. To this end, this article suggests a method for identifying the merits and demerits of using slow motion to analyse actions, and discusses the methodological implications of temporality in observation.
\end{abstract}

Keywords Sociology of time · Theory of action · Phenomenology · Slow motion · Video analysis

Alexander Schmidl

Alexander.Schmidl@fau.de

1 Institute of Sociology, Friedrich-Alexander-University Erlangen-Nürnberg, Kochstraße 4, 91054 Erlangen, Germany 


\section{Introduction}

It is the 2018 World Cup Final between France and Croatia in the Luzhniki Stadium in Moscow. In the 34th minute, France are awarded a corner kick. France take the kick and the ball passes just a few metres from the goal. Blaise Matuidi turns towards the ball and it glances off his head and upper arm. The ball continues on to Ivan Perišić, who is standing half a metre or so behind Matuidi. The ball touches Perišić on the underside of his wrist and goes out of play behind the goal line. The head referee reviews the situation using video footage and awards a penalty to France, which Antoine Griezmann scores to restore France's lead. ${ }^{1}$

What happened? At the time of the controversial incident, the head referee was roughly $21 \mathrm{~m}$ away from the players and could only see the two men from behind due to his position on the pitch. His initial judgement was that there had been no infringement of the rules. However, the video assistant referee had access to camera footage, and thanks to the large number of cameras (there are probably few events with as many as this) he was able to review the action repeatedly and in slow motion. The video assistant referee then drew the head referee's attention to the possibility of an intentional handball. The latter then stopped the game, went to the touchline, checked the video footage and conferred with the video assistant referee. They had to decide if the player had touched the ball intentionally with his hand because only then does this constitute an action that can be punished by the awarding of a penalty kick. The time it took for the ball to glance off Matuidi and touch Perišić's hand was between 0.005 and $0.022 \mathrm{~s}$ in real time, ${ }^{2}$ making it hard to say whether Perišić acted intentionally in such a short space of time. However, in the slow-motion version of events it can take several seconds for the ball to reach Perišić. In this stretched time period, he follows the ball with his eyes, lowers his hand in the direction of the ball and puts it intentionally out of play. The slow motion replay stretches out the fleeting moment in all its detail and the referees ultimately decide to award a penalty.

This simple example begs the question what exactly becomes visible in the slow motion footage. From the perspective of sociology and action theory, it is particularly interesting to study what influence slow motion has on observation and the evaluation of actions. This study therefore focuses on the role temporality plays in understanding actions. In other words, this study is about the temporality of actions, to which media technology provides us with a new point of access, and thus ultimately about intersubjective understanding. However, it remains to be seen how far the slowing down of an observed action actually helps us to view intentions and processes more closely and whether this might be of interest to action theory and methods of qualitative research.

\footnotetext{
1 For the Highlights of the Game see: https://www.youtube.com/watch?v=GrsEAvRerTg (FIFATV: “2018 World Cup Final: France 4-2 Croatia,” accessed 22 March 2021), particular timestamp 0:47-0:48.

2 It is not possible to establish the exact period of time, first because it is unclear when the relevant action begins for Perišić, and second because the video sequence does not run smoothly even at a rate of 60 images per second because two images have a real time interval of $0.0166 \mathrm{~s}$.
} 
The article is structured as follows. First, the article establishes the significance of temporality for actions and the situative and physical conditions affecting it. Second, it undertakes an analysis based on phenomenological sociology which assesses how one person's temporal perception can be linked to the temporal perception of others. Proceeding from Luckmann (1983), the foremost question is how people synchronise their feeling for time and arrive at a common time or at least develop an understanding of another person's feeling for time. In contrast, Garfinkel conceptualized a different notion of interactive time (Rawls 2005). Instead of asking how different subjects can come together, in Ethnomethodology intentionality can be seen as an interactively generated intentionality at best. The discussion then returns to the example of slow motion in football to set out the assumptions underlying the temporality of action and observation in practice. This topic also contains a discussion of Goodwin and Goodwin's (1997) findings on discursive practices of image interpretation. The major point, however, is, that the soundless slow motion images are drawing the attention to the body in action. Hence, the discussion is then augmented by Merleau-Ponty's phenomenology ([1945] 1981, [1952] 1993), albeit with a stronger emphasis on the body in the formation, carrying out of and visibility intentions, and a broader concept of intentionality. The increasing use of media is the case in the social sciences, where the use of video material is also increasingly common. Using time-, action- and media-theory to clarify what it is exactly that is more visible in slow motion footage also provides an opportunity in the last section of the article to lay a methodological groundwork for studying temporality in empirical action analysis in complement to ethnomethodology. The aim of this article is therefore to use a sociology of slow motion to identify the merits and demerits of using a media-technology-based, time-varying approach to studying actions. This marks a contribution to the process of systematically developing a reliable method for studying the temporality of actions, observation and understanding.

\section{Action and Subjective Time Perception}

In line with Schutz' social phenomenology, it is possible to speak of an action if the following condition is fulfilled. There must be a projected act, meaning that a person must have thought about what steps to take to achieve a certain goal. Here, it is not important for a person to attain their goal as intended, but they should at least have engaged in a process of planning their action (Schutz [1932]1967: 57-63). Moreover, it can be said that there must be several alternatives of action which the person can weigh up and choose between (Parsons et al. [1951] 1962). If both conditions are fulfilled, it would be possible to speak of meaningful and intentional action. Though, this view of planned actions has also been subject to criticism. One of the major contributions to the theory of action and questions like these had been made by Lucy Suchman (1985). She showed that in complex situations like technical workplaces, actions are not planned and executed directly but rather have to be adapted again and again due to the changing circumstances. The challenge is at all to determine how much time a person needs before it can be said that they have considered and planned an action. It is equally difficult to identify when the thinking 
and choosing take place. With regard to time, Schutz in his work about "Making Music Together" points to the fact, that " $[\mathrm{t}]$ he outer time is measurable" but that " $[\mathrm{t}]$ here is no such yardstick for the dimension of inner time (...)" (1951: 89). Indeed, the amount of time available to someone cannot be calculated using a physical or an objective time structure. It is more a question of a person's subjective feeling for time. Whether they actually make a decision or not, therefore, depends on a person's subjective perception of time and the time available to them.

Describing conscious time has been a challenge in philosophy at least since Augustine. Husserl shows some commiseration by looking at Augustine's struggle with immediate experience and Presentism calling it an "ancient burden for descriptive psychology and epistemology" ([1928] 1991: 3). Momentous for the philosophy of the conscious time has been Henri Bergson's doctoral dissertation "Time and Free Will. An Essay on the immediate Data of Consciousness “ ([1913] 2001) where he elaborated on the concept of the durée as the connection between action in consciousness and inner time. Following on from this, Edmund Husserl ([1928] 1991) devoted himself to describing the consciousness of internal time and noted that lived time could most certainly be something different, a finding that a number of researchers including Paul Ricœur (1988) went on to discuss at length. Empirical research from a number of disciplines revealed the number and the variety of causes which gave rise to different subjective time perceptions in relation to speed. Furthermore, it was established relatively early at the mental level that emotions in general play a role (Cohen 1981: 269) and that a person's feeling for time changes as a result of hypnosis (Cooper and Erickson 1950), drug use (Fischer 1946: 308) and schizophrenia (Hannibal 1955). Physical factors also play a role, such as age (Feifel 1957), illness (Cohen 1981: 269) and body temperature (Fraser 1970: 639). With regard to socio-psychological and cultural factors, Knapp and Garbett analysed idiomatic expressions and found that there was a different time perception in people with different cultural backgrounds. People used metaphors to describe time variously as an endless space or never-ending stairs. Another example is to be found in the early modern period in the West, from the pen of Shakespeare, who described time as a thief, conjuring the image of time rushing away which should be dealt with without delay (Knapp 1972: 312-319). In situational contexts, expectations are the main point of reference for time perceptions: monotony makes time pass more slowly, happiness makes it pass more quickly (Schmied 1985: 86-88). That time is experienced as more or less pleasant is clear to anybody who has had to endure the social phenomenon of waiting. In "To Wait and Let Wait" (2015), Andreas Gottlich discusses such blank spaces in time. He finds among other things that they are the result of exercising power on the level of time.

Examples from the field of sport are also useful for shedding light on subjective time perception. In the 1960s, early research (such as Langer et al. 1961) indicated that at especially critical moments, the length of a particular action sequence may subjectively feel longer. John Brodie, the former Quarterback for the San Francisco 49ers describes these moments as follows:

At times, and with increasing frequency now, I experience a kind of clarity that I've never seen adequately described in a football story. Sometimes, for exam- 
ple, time seems to slow way down in an uncanny way, as if everything were moving slow motion. It seems as if I have all the time in the world to watch the receivers run their patterns, and yet I know the defensive line is coming at me as fast as ever. I know perfectly well how hard and fast those guys are coming and yet the whole thing seems like a movie or a dance in slow motion. (quoted in Murphy and Brodie 1973: 19f.)

Jackie Stewart provides a similar description of motor racing. Rather than describing it as something that is happening to him, he sees it as a particular skill that is of decisive importance for the competition:

... what separates the great driver from the mediocre driver, is, among other things, the ability to 'go slow' in a special way that ordinary mortals experience only in dream or drugged state, to slow down time, and thereby perceived event, by speeding up perception. (quoted in Purdy 1981: 94)

Statements by athletes in tennis and baseball to the effect that the ball slows down just before they hit it with their racquet or bat were the starting point for an experimental, psychological study by Hagura et al. (2012). They found that a person's perception was at its most acute at this decisive moment so they could quickly adjust their movements to strike the ball in the optimal manner (Hagura et al. 2012: 4405). Their high tension of consciousness and the resultant increase in competence gave the athletes the impression that they had more time (Hagura et al. 2012: 4405).

It is therefore important to note at this point in the study that there is a correlation between the tension of consciousness that exists in the situation as a result of relevance structures and a person's subjective time perception. If we aim to understand how someone acts and takes decisions, it is therefore necessary to know how their time is structured, or at least bear in mind that time can be perceived very differently depending on the situation and a person's attention levels.

\section{Interaction and Intersubjective Time Perception}

That time is relative ranks as one of the most important discoveries of modern science and had been systematically investigated in philosophy by Henri Bergson. In addition to Bergson's work, studies by Heidegger ("Being and Time" ([1927] 1962)) and Husserl ("On the Phenomenology of the Consciousness of Internal Time" ([1928] 1990)) laid the foundation for establishing a connection between experience, lived experience and time. Indeed, most classifications of time are based on these works. Whilst Bergson ([1913] 2001) differentiates between subjective conscious time and external time, Heidegger ([1927] 1962) differentiates between primordial and authentic time on the one side and the ordinary conception of time on the other side, and Husserl between phenomenological and doxic time (Schmied 1985: 27). Bergson's differentiation was influential for most subsequent approaches. Later discourse saw the terminological distinction between subjective and objective time become more established (Schmied 1985: 28). Sociology, which found little use for Newton's concept of absolute time - as an unchanging external fact which cannot be 
influenced by humans - found this especially attractive, because it clearly delineates the time of individual consciousness (durée) (Schmied 1985: 33-66; Nassehi 1993: 113). In a further definitional step of interest to sociology, external time was not only no longer viewed as unchanging natural time, but as social time (as outlined, i.a., by Schmied 1985: 35).

Although the aspect of social construction of time already had been taken into account, this outer and social time remains abstract. As Anne Rawls (2005: 168) points out, Garfinkel's aim was to detect the "situated and socially produced character of all aspects of social orders" which a particular concept of time stands for. Inbetween the historical social time and the inner time (which are representing positivism and solipsism) he places the "interactional time" (Rawls 2005: 168f.). Just as social orders are produced through interactions, this sort of time evolves in the situated actions too. It is not a time that already exists, but it is produced by the related actors (Rawls 2005: 171). Thus, this "sequential time is experienced simultaneously, and in the same way, by all participants" (Rawls 2005: 173).

Thomas Luckmann, from a somewhat different school of thought and without paying much attention to Ethnomethodology, as he self-committed in an interview in 2011 (Ayaß and Meyer 2012b), categorised time in similar terms. ${ }^{3}$ He differentiated between (a) inner time of the individual body, (b) intersubjective time and (c) already socially objectivated categories of time (Luckmann 1983). This allowed him to better describe the gradual step-by-step processes between the internalisation and externalisation of time. Luckmann's inner, intersubjective and social time are therefore not to be understood as mutually exclusive categories, but as categories that complement one another. ${ }^{4}$

How it is possible to establish any form of coordination between interaction partners despite their different perception of time? In the light of Ethnomethodology, there might be these differences, but for the success of the interaction, only the shared interactional time is of relevance. Necessary, therefore, is copresence and reciprocity - what is mostly the case for interactions in the normal course of life, isn't the case when observing actions in slow motion.

Luckmann's approach is different. He takes singular individuals with their own consciousness for granted and asks, how it is possible, despite all of these differences, for one person to understand the processes of action of another. On the one hand, it might be claimed that each individual has their own perception of time and that their view of someone else's lived experience must remain limited; on the other

\footnotetext{
3 Luckmann's model leans more towards Husserl's phenomenology. However, he does follow in direct line from the "Stratifications of the Life-World" which Schutz started and Luckmann himself continued, which included not only a social and spatial, but also a temporal aspect (Schutz and Luckmann 1973: 45-58), and which closely mirrors Bergson regarding time. However, Schutz ([1932] 1967: 36, 70) had already pointed out in his early work that Bergson's durée and Husserl's Consiousness of Internal Time can be considered equivalents.

4 Nevertheless, Werner Bergmann (1988: 87) did accuse him of giving consciousness too dominant a position in the constitution of time, without giving enough consideration to the social repercussions. This was a criticism that had already been levelled at Husserl by Bieri (1972: 177-221) when he demonstrated that Husserl's attempt to argue that time was constituted from consciousness alone failed, because Husserl already was forced to include external circumstances as well.
} 
hand, one might argue that people possess an innate ability to place themselves in other people's time structures. Whilst Bergson dealt primarily with the first view, Schutz (in light of the problem of intersubjective understanding and the general thesis of the alter ego) ([1932] 1967: 97-138) and later Luckmann devoted themselves more to the question, how different perceptions of time are interlaced. Luckmann claimed that, for interactions to take place, the actions of the interaction partners had to be coordinated, which is why he speaks of a "synchronization of two streams of consciousness" (1983: 78). His premise is therefore that there are two streams of consciousness, each with their own temporal structures - Bergson's durée - which align with each other or at least coordinate to enable successful interaction. Of equal importance for this form of alignment or coordination is the temporal aspect of intersubjective understanding. Because the rhythms and speeds of the interaction partners align, a common temporal structure forms, or at least a high level of understanding for the temporal structure of the other person's consciousness, with which the other partner can align themselves. However, Luckmann (1983: 79) introduces a caveat here, saying that coordination between interaction partners can only take place in the copresence of others. Like Schutz, and in collaboration with Peter L. Berger in "The Social Construction of Reality" ([1966] 1991), Luckmann refers to a kind of core situation in social interaction - the face-to-face encounter - in which the individuals are in each other's immediate vicinity and can read each other. ${ }^{5}$ However, increasing typification of these kinds of coordination and actions meant that they became increasingly distant from actual individuals and situations. Ultimately, social time structures emerged and became established, and these in turn exerted an influence on people's perception of time. ${ }^{6}$

Just as Garfinkel's conception of time, copresence and alternating actions are important for Luckmann too, since under these circumstances an adequate understanding of others in relation to time is most likely. But with the conceptions of internalisation and externalisation, as well as the abstract form of understanding via typification, he leaves the door open. In comparison, Garfinkel's intersubjective time is ultimately bound to situations of interaction. For this reason, completely new

\footnotetext{
5 As Berger and Luckmann explicate it: "In the face-to-face situation the other is appresented to me in a vivid present shared by both of us. I know that in the same vivid present I am appresented to him. My and his 'here and now' continuously impinge on each other as long as the face-to-face situation continues. As a result, there is a continuous interchange of my expressivity and his. I see him smile, then react to my frown by stopping the smile, then smiling again as I smile, and so on. Every expression of mine is oriented towards him, and vice versa, and this continuous reciprocity of expressive acts is simultaneously available to both of us" ([1966] 1991: 43). This is why Luckmann sees himself compelled to mention communication by mail and telephone as non-copresent but synchronous forms of interaction, but he then immediately excludes them from his studies.

${ }^{6}$ From the perspective of Bieri and W. Bergmann, this last step - as indicated earlier - ultimately receives too little consideration. They give greater stress to the opposite direction of action and also point out in detail that it is not even actually possible to synchronise the streams of consciousness without an external time-giver (Schulte 1996: 63). Or following on from Schulte (1996: 64), phrased provocatively: In actual fact, actions become synchronised with the objective time structure, not the streams of consciousness. For a discussion on excluding consciousness from considerations on the alignment of actions with respect to temporal structure, please refer to George Herbert Mead, with whom W. Bergmann (1981) established a connection.
} 
questions arise in understanding actions in data analyses which will be addressed in the last section.

\section{Applications of Slow Motion}

Football used a definitorial approach to solve the question of how visible action and intentions are connected. When a player touches the ball with the hand, an offence has been committed only in case of an intentional touch. In order to assess this, the rules of the International Football Association Board (IFAB) require the referees to take the following into account: "the movement of the hand towards the ball (not the ball towards the hand)", "the distance between the opponent and the ball (unexpected ball)" and "the position of the hand does not necessarily mean that there is an offence" (IFAB 2017: 96).

The IFAB proceeds from the premise that there is a connection between visible actions and the players' intentions. It is therefore possible to establish which movements, positions and distances signify an intentional handball. By specifying the circumstances in this way, the IFAB established norms for how the referees observe the game, and how they should interpret the game and the images in the video footage. Here, Charles und Marjorie Goodwin speak of "[t]he power of coding schemes to control perception" (1997: 293). The findings of Goodwin and Goodwin are based on years of research in which video recordings were made, and a study on the use of a video in a court case against four police officers. The four police officers in the video had launched an extremely violent attack on Rodney King on 03.03.1991. The video recording of the events made by a local resident was the main focus of public debate and the key piece of evidence in the subsequent court case. In their analysis, Goodwin and Goodwin show how the defence team's strategy consisted of breaking down the video into its individual images and using experts to shift the focus onto Rodney King and his alleged refusal to cooperate with the police, rather than the police officers striking King. The defence team argued that images are not self-evident but must be interpreted in a certain way (Goodwin and Goodwin 1997: 293), which exemplifies that many interpretations are possible and certain ones can be enforced by powerful actors. Mirroring this, the IFAB defines when the referees are witnessing a planned and intentional action. The IFAB therefore codifies which visible bodily movements count as intentional actions and at the same time chooses a very broad definition of consciousness and intention. The referees then put these prescriptive definitions into practice, afterwards invoking the rules-based character of sport, the objective character of the images and their "professional vision" (Goodwin 1994) in support of their decisions. Sport may be a special case because some associations, like it is the case in football, define the proceedings of image production and interpretation in order to control the discourse throughout (Schmidl 2021). However, it does show where the crucial points in using slow motion to identify intentionality lie. After possible rule infringements had been checked in some important games in slow motion, critical voices about checking intentional handball emerged. The IFAB took this into account and reformulated their rules in 2020: The video assistant referee can use "different camera angles and replay speeds, 
(...) but in general, slow-motion replays should only be used for facts, e.g. position of offence/player, point of contact for physical offences and handball, ball out of play (including goal/no goal); normal speed should be used for the 'intensity' of an offence or to decide if it was a handball offence " (IFAB 2020: 145). Ultimately, the FIFA suspended slow motion image from many decision-making processes, but in general, the players are well aware of the observation of all their actions. In training sessions, video recordings are also used and, as Brümmer was able to show in her research on training sessions in professional football, the players themselves are looking at video recordings as "self-evident representations of reality" (2018: 361).

\section{Observing the Actions of the Body}

In any event, the importance of the body becomes apparent. The images of actions and interactions in slow motion are soundless and the visible movements come to the fore. In the context of the discussion about the relation between body and intentions, it might be said that the actions in a game might have been intentionally acquired, repeatedly trained and then manifest themselves in the game. Seen in this way, a handball might be viewed as intentional in a broad sense even if the player's action in the situation is not thought through, but if the player has always factored in the possibility that they might touch the ball with their hand and that it will be observed in video footage.

Slow motion is a technical tool which can be used to slow down the duration of a visible action so that it can be watched afterwards. In light of Garfinkel's sequential action and interactive time, the problem of (mis-)understanding lies in the lack of reciprocity between actor and interpreter. As he wrote: "The problem is to recover the phenomenon as a prospective achievement rather than a retrospective account" (Garfinkel 2002: 34). Viewed from the perspective of Luckmann's principle of synchronization of streams of consciousness using slow motion premeditatedly disconnects one perception of time from another. From this perspective, slow motion tends to counteract the understanding. Here, one might of course interject that the subjective time perception of individuals might also be slowed down. This is because, as mentioned above, people's attention levels rise so dramatically at particularly important moments that they experience the events taking place around them far more intensively and therefore subjectively more slowly. This slowing down might potentially equate to the slowing down of slow motion footage. But it remains unclear how much more slowly a player subjectively experiences a situation and what correction factor would have to be factored in to the camera footage. From this perspective, we must continue to assume that viewing actions in slow motion actually distorts rather than improves the observer's understanding. This means that because the speed of the observed action does not correlate with the subjective experience of the action, it is not possible to evaluate the action, its intention or its meaning.

It must be borne in mind here, however, that Luckmann is speaking of consciousness in the narrow sense of the term. Interestingly, he stresses that a synchronisation of streams of consciousness can essentially only take place in a copresent situation (which would of course not be the case with viewing actions 
in slow motion). Without going into this in any greater depth, Luckmann's theory gives particular prominence to the body.

As a result, we should consider including the body, or the felt body to be precise, in a broad definition of consciousness. This would also mean understanding intentionality and meaning as categories of the body and, accordingly, asking how far this body might be better understood in slow motion.

Interpreting the other is a matter of interpreting signals, as Schutz states:

In what follows, let us, for the sake of simplicity, disregard those products of action which refer back to the action itself and limit ourselves to the consideration of the changes in the body of the other person which render his action visible to the observer. These changes function as indications of the other person's inner life, for his body is no mere physical object, like a stick or a stone, but a field of expression for the life-experience of that psychophysical unity we call the other self. (Schutz [1932] 1967: 22)

This means that we interpret external signals and try to infer internal processes from them. Viewed in this way, our consciousness uses the body as a means of expression. The body achieves a measure of autonomy when it becomes the medium for certain forms of knowledge. These include what Schutz and Luckmann (1973: 105f.) refer to as skills and the knowledge of recipes which we are not fully aware we have access to but which the body carries as tacit knowledge. It should nevertheless be borne in mind that actions can be specifically and deliberately practised and trained or even learned only semi-consciously, before they become habitualised actions, routines or recipes. Kissmann (2014) therefore follows Bongaerts' reflections on the "practice turn in social theory" (2007) in making a clearer distinction between routine actions and habitual actions. She understands routine actions as being those which a person engages in fully consciously and which over time retreat into the preconscious. Habitual actions, in contrast, are types of action that are acquired preconsciously and subsequently remain in the preconscious and exert an influence from there (Kissmann 2014: 81f.). In this case, cognitive awareness plays only a peripheral role. It is not possible to say, for example, that a person takes a decision but the body can act spontaneously on the basis of practiced routines. However, these kinds of actions are equally meaningful if we take a broader understanding of meaning because the body is already acting meaningfully or there has been an original decision upon which this routine action is based. This would then also mean that we are dealing with intentional actions.

It is certainly the case that the body plays a role in virtually all social contexts. Further study should however be devoted to examining the extent to which it is intentionally trained. In sport, for example, certain actions are practiced and trained over and again. This results in routine actions, as defined by Kissmann. These can be used repeatedly in certain given situations. However, it is harder to trace habitual actions back to an original action or to give them a precise name in the action process. These types of action are, however, very common in social contexts.

Whilst Schutz and Luckmann see the body as being implicitly important, they ultimately view it as a means of expression for the consciousness. Merleau-Ponty 
takes a similar position in selected passages of his work, such as the following example from his "Phenomenology of Perception":

The discussion conducted on these lines certainly discredits the idea of a body storage of the past: the body is no longer a receptacle of engrams, but an organ of mimicry with the function of ensuring the intuitive realization of the 'intentions' of consciosness. (Merleau-Ponty [1945]1981: 413)

However, following on from this and with growing emphasis later is the view that the body develops its own intentionality. This bodily intentionality gives the body its own form of being-to-the-world. This worldly reference is meaningful, and it also creates a basis for social interaction because it gives rise to reciprocal referencing, as recent research has pointed out repeatedly (Kissmann 2014: 107-117; Gugutzer 2020). These kinds of relations exist even before a more conscious connection takes place. So whilst Schutz and Luckmann describe the actions of the body as following an act of consciousness, they might also be understood as preceding (a narrower understanding of) consciousness. It is worth stressing here though that this should not be understood in the sense of a Cartesian duality of body and mind, which begs the question whether the body is active beforehand or afterwards. Research - most recently in the field of embodied cognition (especially Gallagher 2005) - for the most part speaks against such a division. It is therefore of greater importance here to name the potential points at which the body can come into play in a broader understanding of consciousness (see the discussion in Sebald 2014: 37).

Insofar as meaning content can be ascribed to the body, it is still necessary to clarify what role temporality plays here. ${ }^{7}$ As Kissmann (2019) has shown, the emphasis on time definitely changed the focus of Merleau-Ponty's work. In his early work, he distances himself from the concept of linear time, primarily to emphasize current lived experience which is not just a consequence of the past or preparation for the future (Merleau-Ponty [1945]1981: 411-414). But this did not solve the problem of sense-making, which he only managed to clarify successfully in The Visible and the Invisible with the concept of time as chiasm (Kissmann 2019: 26). In his working notes, he speaks of a mesh of past and present (Merleau-Ponty 1968: 268), which Kissmann (2019) uses to revise the concept of body intentionality. In contrast to Schutz or Berger and Luckmann, the body, in this case, is not just an expression of consciousness, but there is a special kind of sense-making on a pre-reflexive level (Kissmann 2019: 30f.). Of particular interest in relation to time perception and its understanding is Merleau-Ponty's explicit critique of slow motion. Whilst Henri Matisse is said to have been thrilled by slow motion recordings of painting, seeing them as an opportunity to reveal the long-concealed creative process-especially his own-, Merleau-Ponty did not share his enthusiasm:

That same brush that, seen with the naked eye, leaped from one act to another, was seen to mediate in a solemn, expanded time-in the imminece of a world's

\footnotetext{
7 For a more precise discussion of temporality in connection with the difference between body (having a body) and felt body (being a body), see the article by Wehrle (2020).
} 
creation-to try ten possible movements, dance in front of the canvas, brush it lightly several times, and crash down finally like a lightning stroke upon the one line necessary. Of course, there is artificial in this analysis. And Matisse would be wrong if, his faith in the film, he believed that he really chose between all possible lines that day and, like the God of Leibniz, solved an immense problem of maximum and minimum. He was not a demiurge; he was a human being. He did not have in his mind's eye all the gesture possible, and in making his choice he did not have to eliminate all but one. It is slow motion which enumerates the possibilities. (Merleau-Ponty [1952] 1993: 82f.)

After the event, according to Merleau-Ponty, a simple gesture seems as though it has been selected from an endless number of possible actions, which in reality do not exist. This illusion occurs because the observer looks at slow motion images in the same way they do real time in the human and physical world. In reality, however, they show the observer a world which takes place beyond that and which cannot be observed using the same criteria (Merleau-Ponty [1952] 1993: 83). Slow motion gives the observer ways of viewing actions which the people doing the actions did not have at their disposal in their perception of time. As initially mentioned, one way of defining an action is when a person chooses from various options. But whilst these options are apparent in slow motion, they are not available for the person in the situation who is carrying out the actions. Added to this is Merleau-Ponty's above-mentioned emphasis on the fact that actions involving the body are primarily a lived present. Viewing such actions in a different context (especially only certain extracts from a particular viewpoint) would in the mind of Merleau-Ponty contradict the sense of the action.

Walter Benjamin seems to have been similarly sceptical about slow motion. In his view, it did not present an opportunity to clarify that which already existed, but to discover the unknown in the known, which gives rise to retarded and supernatural motions. "Evidently a different nature opens itself to the camera than opens to the naked eye - if only because an unconsciously penetrated space is substituted for a space consciously explored by man" (Benjamin [1936] 2005: 24). Merleau-Ponty makes a similar point when he talks about the alienation of technology and doubts the role of technology in the advancement of knowledge. In his view, technology would give rise to phenomena which were "more likely produced by the apparatus than recorded by it" (Merleau-Ponty [1961] 1993: 122).

Whereas the synchronisation of streams of consciousness might be beneficial for intersubjective understanding in relation to temporality, it is clear that slow motion does not improve understanding. In fact, it is quite the opposite: it creates a distance between the observer and the time perception of those engaged in the actions and their meaningfulness. What slow motion does show, however, is how the actions take place. If one also ascribes to the body an important role in carrying out and interpreting intentions or even its own form of intentionality, this makes it possible in some respects to observe and understand actions better. What is decisive is that the slow motion does not just make actions longer and more visible, but also opens up methodological considerations about which aspects of actions it makes accessible. The following discusses the methodological implications and proposes 
a method for using slow motion in empirical action analysis based on the previous theoretical foundations.

\section{Methodological Consequences}

The practice of using slow motion reveals which implicit assumptions exist and what certain action groups are trying to reveal by using slow motion. ${ }^{8}$ The use of slow motion and the question of what aspects of action become visible by using it is also relevant to empirical social research. But the latter is also under the obligation to fundamentally discuss the merits and demerits of how technology can change observation. It therefore makes sense to use the existing findings on the temporality of actions and its observation to begin to formulate a methodology for slow motion analysis in empirical social research.

Visual data are becoming increasingly important in qualitative approaches in empirical social research. This is true for images and photographs, for which empirical social research has established methods (Bell 2001; Bohnsack 2010). Video footage is also similarly well covered (Kissmann 2014; Knoblauch et al. 2006, 2014). ${ }^{9}$ However, there is as yet no systematic approach to examining the merits and demerits of observing actions using slow motion. Jörg Bergmann (1985) engages in a comprehensive discussion of the recording of data and its associated challenges. ${ }^{10}$ He states that it is tempting to believe that one is looking at a depiction of reality, even though what one is actually looking at is constructed realism (Bergmann 1985: 317). Video recordings depict just a small and technically limited snippet of reality. The interpretation takes place in a different context to the one in which the action took place and, of capital importance: the time structure and temporality changes. As Bergmann points out, the recorded actions can be viewed in fast motion, in realtime, in slow motion and in still images. It is the decision of the viewer and the apparatus to choose specific images, whereby they determine the action's temporality (Bergmann 1985: 317). In analysing the work in laboratories, Lynch, Livingston and Garfinkel for example emphasize "that reasoning is displayed in the midst of orders of intersubjectively accountable details" wherefore in first-order conversations, texts and other sorts of publicly available materials are considered as data (1983: 206). With slow motion images, there are solely body movements, gestures

\footnotetext{
8 Sport and the legal system are two examples of environments which have witnessed the steady growth of video analysis and the use of refined analytical methods which are also the topic of ongoing discussion. The practice of video analysis in other areas, primarily in amateur fields, has been examined in greater depth by a number of critics including Rene Tuma (2012).

9 The analysis of film is not included here. Whilst this also consists of sociologically relevant material, the focus is very much on the production of images. A discussion more closely related to slow motion would be the analysis of aesthetic practices in film (see, e.g., Brockmann 2013).

${ }^{10}$ Beyond this examination, J. Bergmann has contributed in many ways to Qualitative Research. The Festschrift dedicated to him, edited by Ruth Ayaß and Christian Meyer (2012a), is entitled "Sociality in Slow Motion" which is to be understood as an appreciation for his detailed analyses of processes. In contrast, this paper refers to slow motion as the technological slowing down of visible actions and tries to contribute to the question of the connection between action and temporality in this regard.
} 
and facial expressions available. Thus, aspects such as these need to be addressed using qualitative methods and including visual data. ${ }^{11}$ Bottorf (1994: 257) draws a comparison between the analysis of interviews and videos using slow motion. She takes an initially critical view but comes to the conclusion that it is valid because of its similarity to the intensive line-by-line interpretation of interview transcripts. Slow motion is occasionally mentioned in methods guides, mostly as a technique for broadening perspective which can be used to make certain aspects of actions more visible (Collier 2001: 50; Knoblauch 2012: 73; Schubert 2012: 121f.; Tuma et al. 2013: 34). There are also occasionally discussions about the pros and cons of analysis. For example, Elisabeth Mohn writes in her study on interactions in the classroom:

For a time, I had rejected these scenes as uninteresting. Now they were picked out, reworked in slow motion, put into a film sequence, and presented without sound, which permitted a unique observation. The expressions on the faces seemed to match perfectly the impression of a funeral procession, an impression produced by means of the distancing method of slow motion. In another case, however, slow motion was a completely unsuitable form of visualization. The indeed shimmering glance of a girl with eyes darting back and forth lost its character in slow motion and thus eliminated further possible observations. (Mohn 2012: 178)

Consideration must be given to both the temporality of actions and the temporality of observation. To understand this better, we can use a number of insights gleaned from methods research. First, it must be established whether the video recordings have been produced by the maker of the videos themselves or have been made using existing data. In the former case, this is usually material that has been made in the context of ethnographic studies. This includes contextual knowledge which can be drawn upon, especially about the recorded situation. Because the maker of the video has personally experienced the situation, they can use their impressions comparatively in analysing the temporality of the situation as it happened. In the latter case where existing material is used, no such additional information is available, and if there is, it is only second-hand knowledge. Here, the focus shifts onto analytical methods. Hermeneutic approaches in particular (Kissmann 2014; Raab and Stanisavljevic 2018; Raab and Tanzler 2009) along with sequential analysis are well-suited for documenting very detailed findings in relation to temporality. From a phenomenological perspective, the assumption can be made that experience is also possible through appresentation with respect to speed. The present exists in relation to the absent in the same way as real time exists in relation to the slowing down of time. Out of this ensues a consciousness of the speeds involved and a sensitivity for viewing the actions in slow motion. ${ }^{12}$ The Goodwins explain the significance of

\footnotetext{
11 See also the term "vis-ability" (Schindler 2009) and the work of Schindler and Liegl (2013).

12 The examples cited above about the practice of using slow motion can be understood in the sense that the referees compare their impressions gained during the game with the images or draw a connection to them. On the other hand, court cases draw on existing images and examine them at great length. The differentiation between ethnographic settings and the analysis of existing material serves to stress where the
} 
topic and focus in the image. In qualitative social research it is necessary to use an inductive approach, although this poses the challenge of counterbalancing culturally imprinted ways of viewing the world, or at least being aware of them. In addition to these general guidelines, especially the following points may be relevant to studies involving slow motion: ${ }^{13}$

(a) Actions have their own temporality in subjective lived experience as well as interactions generate their own temporal structures which should be factored in to the evaluation of action processes.

(b) It remains to be clarified what role the body plays in the formation or carrying out of intentional actions and what conclusions can be drawn from the analyses as a result.

(c) Actions have a different effect on the observer depending on the speed at which they are viewed. This leads to the insight that time plays a role in intersubjective understanding. To examine this, it makes sense to run video recordings at various speeds and compare the resulting findings.

(d) As it cannot be assumed from the outset that slow motion makes it possible to see more, it is advisable to take a critical stance and decide on a case-by-case basis whether it makes sense to use slow motion at particular points.

On one hand, by using slow motion, the different perceptions of individual time diverge and the understanding becomes eliminated under these conditions. On the other hand, some techniques of alienation can be useful in interpretation. Hitzler (1986) entitled it an attitude of simulated stupidity and Amman and Hirschauer (1997) described it as a process of alienating its own culture for interpretative purposes. To that end, slow motion cannot be used for a better understanding of the others' intentions in general, or only if a concept of bodily intention is being elaborated on. But, by keeping the points mentioned above in mind, it should be possible to achieve a sensitivity for the temporality of actions, observation and ultimately, intersubjective understanding at all.

\section{Conclusion}

Slow motion does not slow down actions, it stretches out the period of observation and its associated scope for interpretation. Actions have their own temporal structures, and these are bound to the person carrying out the actions and the person observing them. Understanding actions also means understanding these temporal dimensions. Using slow motion to observe actions is therefore ambivalent,

\footnotetext{
Footnote 12 (continued)

focus can be placed. Kissmann's (2014) video analysis is an example showing that these approaches are not mutually exclusive; Knoblauch and Schnettler (2012) stress that videography also contains hermeneutic analysis.

13 In a broader sense, this is also true for sequential analyses, especially when interpretations take place frame-by-frame, creating something akin to super-slow-motion.
} 
especially as the observer has a more detailed view of the actions, making a more detailed analysis possible - but at the same time, the time perception of the person carrying out the actions is disregarded. The feeling often arises that one is observing actions from a superior perspective. However, this article calls for the observer to always remain sensitive to the time perception of the person they are observing, and to always consider the temporal aspects of observation and understanding. The observer must always be in a position to state what it is exactly that is being observed and what conclusions can be drawn from it. As regards theory, it remains to be clarified whether the focus of research should be on establishing how actions are carried out and how interactions take place, whether the body should be understood as a field of expression and whether the underlying intentions should be documented, or if the body has its own intentionality. Slow motion opens up new approaches, but it is not a hermeneutic instrument in itself-it must be used as a heuristic tool. The temporal aspects of the observations and interpretations then become the object of focus themselves. Ultimately, what slow motion, and its judicious use, does give rise to is a sensitivity for temporality in both the action itself and the method of analysis.

Acknowledgements I would like to thank Kornelia Hahn for her inspiring video research, Gerd Sebald for the discussions about body and tacit knowledge in football, and the reviewer for the helpful comments regarding the perspectives of phenomenology and ethnomethodology.

Funding Open Access funding enabled and organized by Projekt DEAL. Not applicable.

Open Access This article is licensed under a Creative Commons Attribution 4.0 International License, which permits use, sharing, adaptation, distribution and reproduction in any medium or format, as long as you give appropriate credit to the original author(s) and the source, provide a link to the Creative Commons licence, and indicate if changes were made. The images or other third party material in this article are included in the article's Creative Commons licence, unless indicated otherwise in a credit line to the material. If material is not included in the article's Creative Commons licence and your intended use is not permitted by statutory regulation or exceeds the permitted use, you will need to obtain permission directly from the copyright holder. To view a copy of this licence, visit http://creativecommons.org/licen ses/by/4.0/.

\section{References}

Amann, K., \& Hirschauer, S. (1997). Die Befremdung der eigenen Kultur. Ein Programm. In K. Amann \& S. Hirschauer (Eds.), Die Befremdung der eigenen Kultur. Zur ethnographischen Herausforderung soziologischer Empirie (pp. 7-52). Suhrkamp.

Ayaß, R., \& Meyer, C. (Eds.). (2012a). Sozialität in Slow Motion. Theoretische und empirische Perspektiven. Festschrift für Jörg Bergmann. Springer.

Ayaß, R., \& Meyer, C. (2012b). Alles Soziale besteht aus verschiedenen Niveaus der Objektivierung'. Ein Gespräch mit Thomas Luckmann. In R. Ayaß \& C. Meyer (Eds.), Sozialität in Slow Motion. Theoretische und empirische Perspektiven. Festschrift für Jörg Bergmann (pp. 21-39). Springer.

Bell, P. (2001). Content analysis of visual images. In T. van Leeuwen and C. Jewitt (Eds.), Handbook of visual analysis (pp. 10-34). London et al.: SAGE.

Benjamin, W. ([1936] 2005). The work of art in the age of mechanical reproduction. Los Angeles: UCLA School of Theater, Film and Television.

Berger, P. L. and Luckmann, T. ([1966] 1991). The social construction of reality: a treatise in the sociology of knowlege. London et al.: Penguin Books.

Bergmann, J. R. (1985). Flüchtigkeit und methodische Fixierung sozialer Wirklichkeit: Aufzeichnungen als Daten der interpretativen Soziologie. In W. Bonß \& H. Hartmann (Eds.), Entzauberte 
Wissenschaft: Zur Relativität und Geltung soziologischer Forschung. Sonderband 3 der Zeitschrift Soziale Welt (pp. 299-320). Schwarz.

Bergmann, W. (1981). Zeit, Handlung und Sozialität bei G H. Mead. Zeitschrift Für Soziologie, 10, $351-363$.

Bergmann, W. (1988). Bewußtsein oder Handlung. Ansatzpunkte einer soziologischen Zeittheorie. In E. K. Seifert (Ed.), Ökonomie und Zeit (pp. 79-101). Hang + Herchen.

Bergson, H. ([1913] 2001). Time and free will. An essay on the immediate data of consciousness. Mineola: Dover Publications.

Bieri, P. (1972). Zeit und Zeiterfahrung. Exposition eines Problembereichs. Suhrkamp.

Bohnsack, R. (2010). The interpretation of pictures and the documentary method. In R. Bohnsack, N. Pfaff, \& W. Weller (Eds.), Qualitative analysis and documentary method in international educational research (pp. 267-292). Verlag Barbara Budrich.

Bongaerts, G. (2007). Soziale Praxis und Verhalten - Überlegungen zum Practice Turn in Social Theory. Zeitschrift Für Soziologie, 36(4), 246-260.

Bottorff, J. L. (1994). Using videotaped recordings in qualitative research. In J. M. Morse (Ed.), Critical issues in qualitative research methods (pp. 244-262). Thousand Oaks: SAGE.

Brockmann, T. (2013). Die Zeitlupe: Anatomie eines filmischen Stilmittels. Schüren.

Brümmer, K. (2018). Subjectivation by video - ethnographic explorations on practices of video analysis in high-performance youth football. German Journal of Exercise and Sport Research, 48(3), $358-365$.

Cohen, J. (1981). Subjective time. In J. T. Fraser (Ed.), The voices of time: a cooperative survey of man's views of time as expressed by the sciences and by the humanities (pp. 257-275). University of Massachusetts Press.

Collier, M. (2001). Approaches to analysis in visual anthropology. In T. van Leeuwen \& C. Jewitt (Eds.), Handbook of visual analysis (pp. 35-60). SAGE.

Cooper, L. F., \& Erickson, M. H. (1950). Time distortion in hypnosis. The Bulletin Georgetown University Medical Center, 4, 50-68.

Feifel, H. (1957). Judgement of time in younger and older persons. Journal of Gerontology, 12, 71-74.

Fischer, R. (1946). Selbstbeobachtungen im Mezkalin-Rausch. Schweizerische Zeitschrift Für Psychologie, 5, 308-313.

Fraser, J. T. (1970). Time as a hierarchy of creative conflicts. Studium Generale, 23, 597-689.

Gallagher, S. (2005). How the body shapes the mind. Oxford University Press.

Garfinkel, H. (2002). Ethnomethodology's program. Working out Durkheim's aphorism. Rowman \& Littlefield.

Goodwin, C. (1994). Professional vision. American Anthropologist, 96(3), 606-633.

Goodwin, C., \& Goodwin, M. H. (1997). Contested Vision: The discursive constitution of Rodney King. In B.-L. Gunnarsson, P. Linell, \& B. Nordberg (Eds.), The construction of professional discourse (pp. 292-316). Routledge.

Göttlich, A. (2015). To wait and let wait. reflections on the social imposition of time. Schutzian Research, 7, 47-64.

Gugutzer, R. (2020). Beyond Husserl and Schütz: Hermann Schmitz and neophenomenological sociology. Journal for the Theory of Social Behaviour, 50(2), 184-202.

Hagura, N., Kanai, R., Orgs, G., \& Haggard, P. (2012). Ready steady slow: Action preparation slows the subjective passage of time. Proceedings of the Royal Society b: Biological Sciences, 279(1746), 4399-4406.

Hannibal, O. (1955). Das Zeiterleben in der Schizophrenie. Studium Generale, 8, 607-611.

Heidegger, M. ([1927] 1962). Being and Time. Southampton: Basil Blackwell.

Hitzler, R. (1986). Die Attitüde der künstlichen Dummheit. Zum Verhältnis von Soziologie und Alltag. Sozialwissenschaftliche Informationen, 15(3), 53-59.

Husserl, E. ([1928] 1991). On the phenomenology of the consciousness of internal time (1893-1917). Translated by John Barnett Brough. Dordrecht, Boston and London: Kluwer Academic Publishers.

International Football Association Board (2017): Laws of the game 2017/18. Zürich. https://footballtechnology.fifa.com/media/1245/lotg_17_18_en.pdf. Accessed 05 April 2021.

International Football Association Board (2020). Laws of the Game 2020/21. Zürich. Available at: https://static-3eb8.kxcdn.com/files/document-category/062020/fXHLhQuMmtekmfe.pdf. Accessed 05 April 2021.

Kissmann, U. T. (2014). Die Sozialität des Visuellen. Fundierung der hermeneutischen Videoanalyse und materiale Untersuchungen. Verlbrück. 
Kissmann, U. T. (2019). What makes sensation of a sentient thing possible: The concept of time in the work of Maurice Merleau-Ponty. In T. U. Kissmann \& J. van Loon (Eds.), Discussing New Materiality (pp. 21-38). Wiesbaden: Springer.

Knapp, R. H. (1972). Personality and the psychology of time. In J. T. Fraser, F. Haber, \& G. Muller (Eds.), The study of time (pp. 312-319). Springer.

Knoblauch, H. (2012). Videography: focused ethnography and video analysis. In H. Knoblauch, B. Schnettler, J. Raab, \& H.-G. Soeffner (Eds.), Video-Analysis: Methodology and Methods Qualitative Audiovisual Data Analysis in Sociology (3rd ed., pp. 69-84). Peter Lang.

Knoblauch, H., \& Schnettler, B. (2012). Videography: Analysing video data as a >focused< ethnographic and hermeneutical exercise. Qualitative Research, 12(3), 334-356.

Knoblauch, H., Schnettler, B., Raab, J., \& Soeffner, H.-G. (Eds.). (2006). Video-analysis: methodology and methods. Qualitative audiovisual data analysis in sociology. Peter Lang.

Knoblauch, H., Tuma, R., \& Schnettler, B. (2014). Videography: Introduction to interpretive videoanalysis of social situations. Peter Lang.

Langer, J., Wapner, S., \& Werner, H. (1961). The effect of danger upon the experience of time. American Journal of Psychology, 74, 94-97.

Luckmann, T. (1983). Remarks on personal identity: Inner social and historical time. In A. JacobsonWidding (Ed.), Identity personal and social-cultural a symposium (pp. 67-91). Almqvist \& Wiksell.

Lynch, M., Livingston, E., \& Garfinkel, H. (1983). Temporal order in laboratory work. In K. Knorr-Cetina \& M. Mulkay (Eds.), Science observed (pp. 205-238). London: Sage.

Merleau-Ponty, M. ([1945] 1981). Phenomenology of perception. London and Henley: Routledge \& Kegan Paul.

Merleau-Ponty, M. ([1952] 1993). Indirect language and the voices of silence. In G. A. Johnson and M. B. Smith (Eds.), The Merleau-Ponty Aesthetics Reader: Philosophy and Painting (pp. 76-120). Evanston: Northwestern University Press.

Merleau-Ponty, M. ([1961] 1993). Eye and mind. In G. A. Johnson and M. B. Smith (Eds.), The MerleauPonty Aesthetics Reader: Philosophy and Painting (pp. 121-149). Evanston: Northwestern University Press.

Merleau-Ponty, M. (1968). The visible and the invisible. Followed by working notes. Northwestern University Press.

Mohn, E. (2012). Permanent work on gazes: Video ethnography as an alternative methodology. In H. Knoblauch, B. Schnettler, J. Raab, \& H.-G. Soeffner (Eds.), Video-Analysis: Methodology and Methods Qualitative Audiovisual Data Analysis in Sociology (3rd ed., pp. 173-182). Frankfurt: Peter Lang.

Murphy, M., \& Brodie, J. (1973). I experience a kind of clarity. Intellectual Digest, 3, 19-20.

Nassehi, A. (1993). Die Zeit der Gesellschaft: Auf dem Weg zu einer soziologischen Theorie der Zeit. Neuauflage mit einem Beitrag "Gegenwarten.” Springer.

Parsons, T., Shils, E. A., Allport, G. W., Kluckhohn, C., Murray, H. A., Sears, R. R., Sheldon, R. C., Stouffer, S. A. and Tolman, E. C. ([1951] 1962). Some fundamental categories of the theory of action: A general statement. In T. Parsons and E. A. Shils (Eds.), Toward a General Theory of Action (pp. 3-29). Fifth Printing. Cambridge: Harvard University Press.

Purdy, S. B. (1981). Of time, motion and motor racing. American. Culture, 4(3), 93-103.

Raab, J., \& Stanisavljevic, M. (2018). Wissenssoziologische Videohermeneutik. In C. Moritz \& M. Corsten (Eds.), Handbuch qualitative videoanalyse (pp. 57-71). Springer Nature.

Raab, J., \& Tanzler, D. (2009). Video Hermeneutics. In H. Knoblauch, B. Schnettler, J. Raab, \& H.-G. Soeffner (Eds.), Video-analysis. Methodology and methods (2nd ed., pp. 85-97). Peter Lang.

Rawls, A. W. (2005). Garfinkel's conception of time. Time \& Society, 14(2-3), 163-190.

Ricœur, P. (1988). Time and narrative (Translated by Kathleen Blamey and David Pellauer) (Vol. 3). London: The University of Chicago Press.

Schindler, L. (2009). The manufacturing of vis-ability. In U. Kissmann (Ed.), Video Interaction Analysis (pp. 135-154). Peter Lang.

Schindler, L., \& Liegl, M. (2013). Praxisgeschulte Sehfertigkeit: Zur Fundierung audiovisueller Verfahren in der visuellen Soziologie. Soziale Welt, 64, 51-67.

Schmied, G. (1985). Soziale Zeit. Umfan, "Geschwindigkeit” und Evolution. Duncker \& Humblot.

Schubert, C. (2012). Video analysis of practice and the practice of video analysis: Selecting field and focus in videography. In H. Knoblauch, B. Schnettler, J. Raab, \& H.-G. Soeffner (Eds.), Video-Analysis: Methodology and methods. Qualitative audiovisual data analysis in sociology (3rd ed., pp. 115-126). Peter Lang. 
Schulte, R. (1996). Zeit und strategische Planung: Analyse der Zeitdimension zur Stützung der Unternehmenspraxis. Springer.

Schutz, A. ([1932] 1967). The phenomenology of the social world. Evanston: Northwestern University Press.

Schutz, A. (1951): Making music together. A study in social relationship. In: Social Research 18/1, 76-97.

Schutz, A. and Luckmann, T. (1973). The structures of the life-world. Translated by R. M. Zaner and H. T. Engelhardt, Jr. Evanston: Northwestern University Press.

Schmidl, A. (2021): Visual discourses in sport. A sociological analysis of the implementation of the video evidence in cycling and football. Visual Studies, 08 Apr 2021, https://doi.org/10.1080/14725 86X.2021.1907782.

Sebald, G. (2014). Generalisierung und Sinn: Überlegungen zur Formierung sozialer Gedächtnisse und des Sozialen. Konstanz and Munich: UVK.

Suchman, L. A. (1985). Plans and situated Actions. The problem of human-machine communication. Xerox Corporation.

Tuma, R. (2012). The (re)construction of human conduct: Vernacular video analysis. Qualitative Sociology Review, 8(2), 152-163.

Tuma, R., Schnettler, B., \& Knoblauch, H. (2013). Videographie: Einfuihrung in die interpretative Videoanalyse sozialer Situationen. Springer VS.

Wehrle, M. (2020). Being a body and having a body: The twofold temporality of embodied intentionality. Phenomenology and the Cognitive Sciences, 19, 499-521.

Publisher's Note Springer Nature remains neutral with regard to jurisdictional claims in published maps and institutional affiliations. 